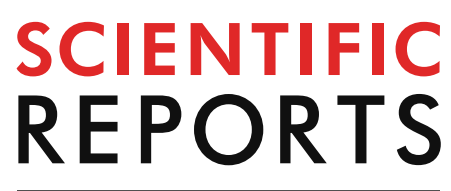

natureresearch

Check for updates

\title{
Phylogeny of the Synlestidae (Odonata: Zygoptera), with an emphasis on Chlorolestes Selys and Ecchlorolestes Barnard
}

\begin{abstract}
John P. Simaika ${ }^{1,2 \bowtie}$, Jessica L. Ware ${ }^{3}$, Rosser W. Garrison ${ }^{4}$ \& Michael J. Samways ${ }^{2}$
The Synlestidae (Odonata: Zygoptera) of southern Africa comprise some highly localized species. All but one species are endemic to South Africa, and many to the Cape Floristic Region. Here we present the first phylogenetic reconstruction of the southern African Synlestidae using nuclear and mitochondrial molecular data. The genera Ecchlorolestes and Chlorolestes are monophyletic, and we propose that the Neotropical family Perilestidae consisting of two genera, Perilestes and Perissolestes, be sunk within Synlestidae. We discuss the intra-familial relationships for the southern African Synlestidae.
\end{abstract}

Distribution. Tillyard ${ }^{1}$ classified species of the family Lestidae as belonging to one of three subfamilies: the Epiophlebiinae, Lestinae, and Synlestinae. Subsequent to this classification, Tillyard ${ }^{2}$ then elevated the status of the subfamily Synlestinae to family level, as Synlestidae. Today, 33 species in the Synlestidae, commonly known as Malachites, are known from Africa, Australia, China, and the Island of Hispanola in the Caribbean. Seven species of Chlorolestes Sélys, 1862 (C. apricans Wilmot, 1975; C. conspicuus Hagen in Sélys, 1862; C. draconicus Balinsky, 1956; C. elegans Pinhey, 1950; C. fasciatus (Burmeister, 1839); C. tessellatus (Burmeister, 1839); and C. umbratus Hagen in Sélys, 1862) and two species of Ecchlorolestes Barnard 1937 (E. nylephtha Barnard, 1937; E. peringueyi (Ris, 1921)) occur in southern Africa (see Fig. S1 for images live specimens and Fig. S2 for presentday species distributions), of which eight are endemic to South Africa, and one (C. elegans) to wider southern Africa $^{3}$. Two Neotropical genera, Perilestes Hagen in Selys, 1862 and Perissolestes Kennedy, 1941, comprising Perilestidae, may be either sister to Synlestidae, or perhaps highly modified Synlestidae ${ }^{4}$. Southern African Synlestidae are the focus of this paper. Additional species included here are Chromisagrion risi Morton, Episynlestes albicaudus (Tillyard), E. cristatus Watson \& Moulds, E. intermedius Theischinger \& Watson, Synlestes selysii Tillyard, S. tropicus Tillyard, and S. weyersii Selys, all of which are endemic to Australia. There are about 16 species in Asia (in two genera, Sinolestes Needham, 1930 and Megalestes Selys, 1868), of which six Megalestes species occur in India ${ }^{5}$. One species, Phylolestes ethelae Christiansen, occurs in the Caribbean ${ }^{6}$.

Here we present a comprehensive phylogenetic reconstruction of the southern African Synlestidae, using nuclear and mitochondrial molecular data. We then discuss the intrafamilial relationships for the southern African Synlestidae with respect to morphological synapomorphies, and comment on the current classification, suggesting that a revision of the group is needed.

\section{Methods}

Taxon sampling. All specimens were field collected. Of the seven known Chlorolestes species, we had specimens of each, as well as both species of Ecchlorolestes. Specimens used in the analyses here are: C. apricans (10 specimens), C. conspicuus (10 specimens), C. elegans (1 specimen), C. fasciatus (5 specimens), C. tessellatus (16 specimens), C. umbratus (10 specimens), E. nylephtha (6 specimens) and E. peringueyi (10 specimens). Despite

\footnotetext{
${ }^{1}$ HE Delft Institute for Water Education, Westvest 7, 2611 AX Delft, The Netherlands. ${ }^{2}$ Department of Conservation Ecology and Entomology, Stellenbosch University, P Bag X1, Matieland 7602, South Africa. ${ }^{3}$ Division of Invertebrate Zoology, American Museum of Natural History, New York, NY 10024, USA. ${ }^{4}$ California Department of Food and Agriculture, 3294 Meadowview Road, Sacramento, CA 95832, USA. ${ }^{\square}$ email: j.simaika@un-ihe.org
} 
several attempts, we were unable to amplify C. draconicus. We included all sequences of Synlestidae from NCBI (Table S2), which added an additional $1428 \mathrm{~S}$ and 8 COI sequences to our dataset.

Gene selection, DNA extraction and PCR amplification. We amplified the nuclear $28 \mathrm{~S}$ ribosomal DNA and the mitochondrial protein coding fragment cytochrome oxidase one (COI). These characters were included in the analysis and, where necessary, coded as missing for our taxa (in our analyses, some taxa had incomplete data; Table S1).

Muscle tissue was extracted using a Qiagen DNEasy tissue kit overnight at $55^{\circ} \mathrm{C}$ with $180 \mu \mathrm{L}$ of ATL Buffer and $20 \mu \mathrm{L}$ Proteinase-K. Older specimens (collected prior to 1980) were extracted with $40 \mu \mathrm{L}$ (twice the suggested amount) of Proteinase-K buffer for several days (2-5 days, depending on the age of specimen, with specimens older than 10 years old left for 2 days, older than 20 years left for 3 days, older than 25 years left for 4 days, and older than 30 years left for 5 days). All other steps followed the manufacturer's protocol. PCR amplification was performed in $25-\mu \mathrm{l}$ (total volume) mixtures by using Ready-To-Go PCR beads (GE Healthcare). We amplified the mitochondrial protein coding gene fragment COI, and the D2 and D3 regions of the 28S nuclear ribosomal subunit. PCR primers (D2ODup, D2DNB, D3up, D3dn) and their sources, are listed in Ware et al. (2007; but for COI we used the universal primers HCO and LCO from Folmer et al., 1994: LCO-1490 5'-GGT CAA CAA ATC ATA AAG ATA TTGG-3', HCO-2198 5'-TAA ACT TCA GGG TGA CCA AAA AAT CA-3'). Programs used for amplifications were (a) $96^{\circ} \mathrm{C}, 3 \mathrm{~min} ; 94^{\circ} \mathrm{C}, 30 \mathrm{~s} ; 50^{\circ} \mathrm{C}, 30 \mathrm{~s} ; 72{ }^{\circ} \mathrm{C}, 45 \mathrm{~s}$ for $35-40 \mathrm{cycles} ; 72^{\circ} \mathrm{C}, 10 \mathrm{~min}$ and (b) $96^{\circ} \mathrm{C}, 3 \mathrm{~min} ; 94^{\circ} \mathrm{C}, 30 \mathrm{~s} ; 46^{\circ} \mathrm{C}, 30 \mathrm{~s}, 72^{\circ} \mathrm{C}, 45 \mathrm{~s}$ for $10 \mathrm{cycles} ; 94{ }^{\circ} \mathrm{C}, 30 \mathrm{~s} ; 48^{\circ} \mathrm{C}, 40 \mathrm{~s} ; 72{ }^{\circ} \mathrm{C}, 45 \mathrm{~s}$ for 30 cycles; $72^{\circ} \mathrm{C}, 10 \mathrm{~min}$. A Qiagen QIAquick PCR purification kit was used to purify amplified product (via silica-gel-membrane spin-column centrifugation, using buffers $\mathrm{PB}, \mathrm{PE}$ and $\mathrm{EB}$ according to the manufacturer's instructions), which was then sequenced on an ABI 3100 capillary sequencer. Sequences from forward and reverse strands were compared and edited in Sequence Navigator ${ }^{7}$.

Alignment. Initial sequence alignments were made using CLUSTAL- $\mathrm{X}^{8}$ and the resulting $28 \mathrm{~S}$ files were then aligned manually in Microsoft Word using secondary structural models.

Phylogenetic reconstruction. Data were partitioned and analyzed using IQTREE 2 (Trifinopoulos et al., 2016), and separate gene trees were also reconstructed. For the combined dataset, a GTR $+F+R 3$ model $^{9}$ was $^{2}$ implemented; for the COI only tree a TIM $2+\mathrm{F}+\mathrm{G} 4$ model and for the $28 \mathrm{~S}$ only tree a $\mathrm{TN}+\mathrm{F}+\mathrm{R} 2$ model were implemented.

Biogeographical analyses. We evaluated geographical patterns in Synlestidae using the parsimony ancestral state reconstruction function in Mesquite ${ }^{10}$. We assigned the taxa in our phylogeny to one or more of three biogeographical regions: Southern, New World, Central Africa and Australasia. We ran these analyses on our consensus maximum likelihood tree. We set no constraints, and taxa were considered to have equal ability to disperse to each area.

Morphology. We examined the morphological features of several adult Synlestidae (Ecchlorolestes, Chlorolestes, Nubiolestes Fraser, 1945) using standard stereo microscopy, to assess synapomorphies among and within the genera Ecchlorolestes and Chlorolestes. We describe these traits below. We evaluated trait evolution patterns using the parsimony ancestral state reconstruction function in Mesquite $^{10}$. We ran these analyses on our consensus maximum likelihood tree.

(a) Head traits (Fig. 1): There was no discernible difference among Ecchlorolestes and Chlorolestes in their epicrania or labra; Chlorolestes conspicuus (Fig. 1D) and Ecchlorolestes peringueyi (Fig. 1I) and, to a lesser extent, C. umbratus (Fig. 1G) have large postocular lobes. Pronounced postocular lobes are absent in Perilestes (Fig. 1A) and Nubiolestes (Fig. 1B).

(b) Wing venation (Fig. 2): In terms of odonate species traits, wing veins are often used to distinguish among taxa. $\mathrm{RP}_{3}$ originates at or just beyond the subnodus in all species of Chlorolestes (Fig. 2C) and in Nubiolestes (Fig. 2B) and one cell beyond in Perilestidae (Fig. 2A) and originates before the subnodus in both species of Ecchlorolestes (Fig. 2D).

(c) Genital ligulae (Fig. 3): Four types of genital ligula were observed among the Synlestidae examined here. In Ecchlorolestes, a sclerotized medial spine on the ligula is absent (Fig. 3E) as in Perilestes (Fig. 3A); in Chlorolestes, C. apricans, C. conspicuus and C. umbratus possess a scleritized medial spine shaped like a scimitar blade with a hollow canal/channel at its tip (Fig. 3C), perhaps for sperm transfer. Chlorolestes draconicus, C. elegans, C. fasciatus and C. tessellatus have a flexible medial spine on the genital ligula with a flap that covers the tip of the ligula, much like a pitcher plant (Fig. 3D). This is perhaps similar to the Nubiolestes form with a sclerotized medial spine tip in the form of a funnel on the genital ligula (Fig. 3B). Kennedy ${ }^{11}$ examined C. fasciatus and C. tessellatus and described a hood-like structure present covering the penis tip in the secondary genitalia of Euchlorolestes (synonymised as Chlorolestes by Barnard ${ }^{12}$ ). This flap-like structure is similar to that of Nubiolestes (Fig. 3B), whose ligula ends in a narrow tip, shaped like a partially flattened funnel.

(d) Male caudal appendages (Fig. 4): Barnard ${ }^{12}$ evaluated the Synlestidae caudal appendages, which were subsequently treated by Pinhey ${ }^{13}$, Tarboton and Tarboton ${ }^{14,15}$ and Samways ${ }^{16}$, and are shown here in more detail. In Chlorolestes (Fig. 4D-J) and Ecchlorolestes (Fig. 4K,L), the paraproct varies in shape specifically. Ecchlorolestes is distinguished from Chlorolestes by the presence of a basal spine on the cercus. Two images 


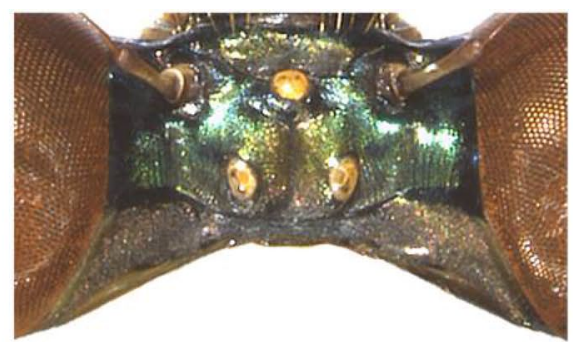

A. Perilestes gracillimus: Suriname, Para River

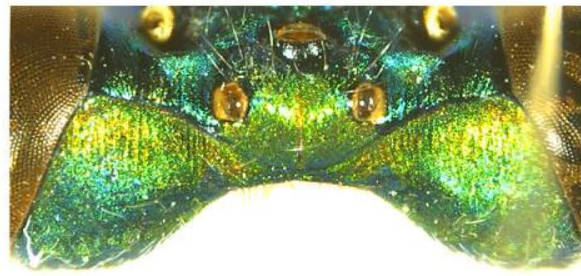

C. Chlorolestes apricans: South Africa, Kubusi River

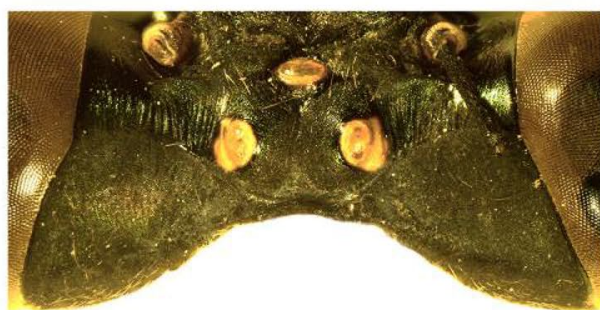

E. Chlorolestes elegans: South Africa, Duiwelskloof

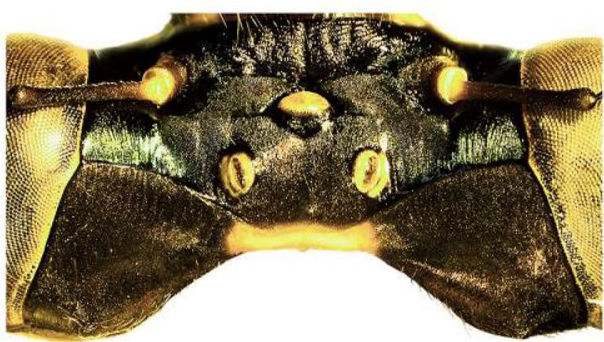

G. Chlorolestes umbratus: South Africa, Harold Porter Nature Reserve

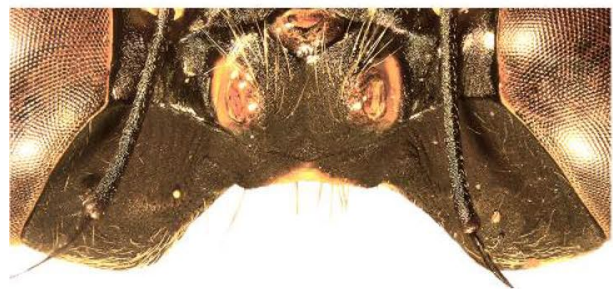

I. Ecchlorolestes peringueyi: South Africa, Eerste River

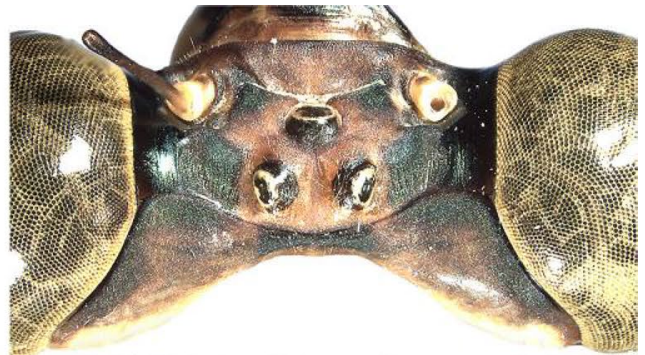

B. Nubiolestes diotoma: Cameroon, Kodmin

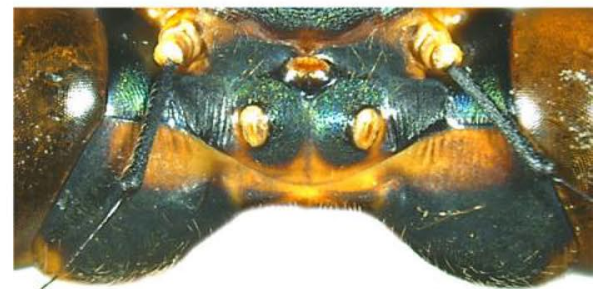

D. Chlorolestes conspicuus: South Africa, Harold Porter Nature Reserve

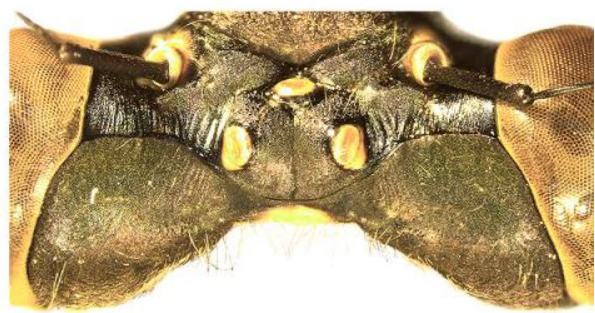

F. Chlorolestes tessellatus: South Africa, Villiersdorp

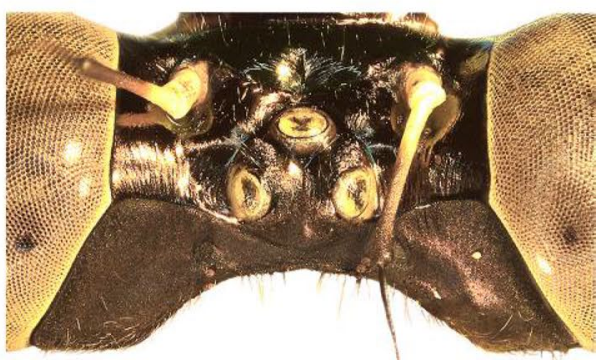

H. Ecchlorolestes nylephtha: South Africa, Bloukrans River

Figure 1. Female epicrania, dorsal view of: (A) Perilestes gracillimus, (B) Nubiolestes diotoma, (C) Chlorolestes apricans, (D) C. conspicuus, (E) C. elegans, (F) C. tessellatus, (G) C. umbratus, (H) Ecchlorolestes nylephtha, and (I) E. peringueyi. 

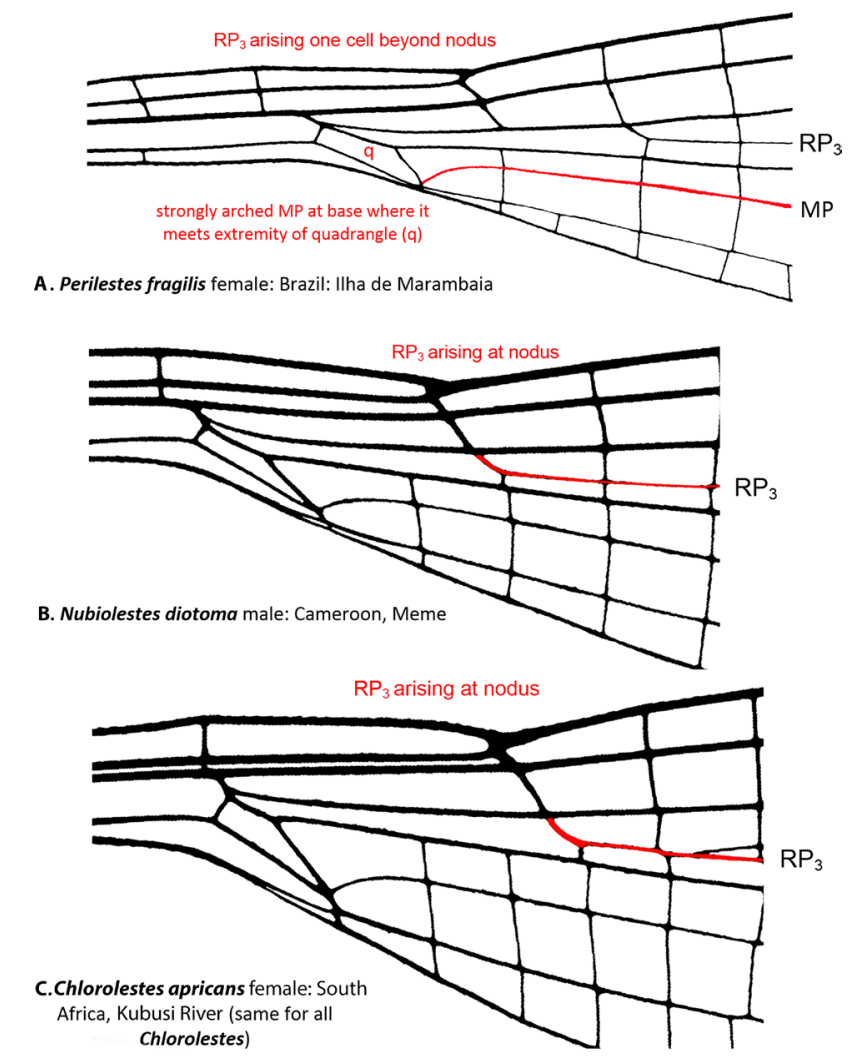

Chlorolestes)

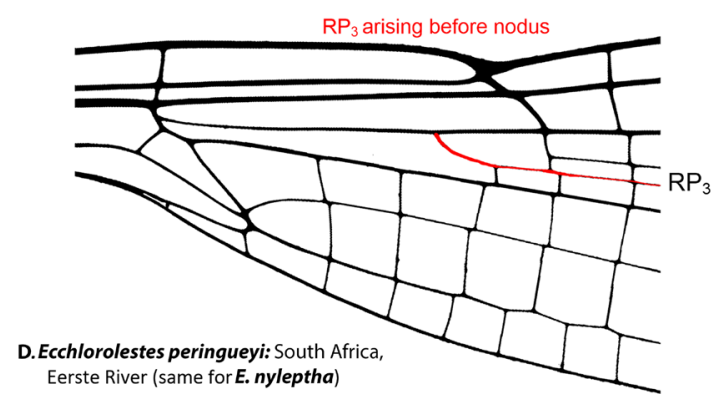

Figure 2. Basal wing venation details of: (A) Perilestes fragilis showing strongly arched MP at base of quadrangle (q), a synapomorphy for all genera included within Synlestidae, (B) Nubiolestes diotoma, (C) Chlorolestes apricans and (D) Ecchlorolestes peringueyi all showing origin of $\mathrm{RP}_{3}$ in relation to nodus.

of Perilestes (Fig. 4A,B) are illustrated here for comparison; they are most similar to Nubiolestes (Fig. 4C) in possessing an expanded distomedial lobe (absent in Chlorolestes and present only in Ecclorolestes peringueyi, Fig. 4L).

(e) Female ovipositor (Figs. 5 and 6): Two distinct types occur in Ecchlorolestes and Chlorolestes. The ovipositor teeth are large, robust and with an apically evenly convex blade in Chlorolestes (Fig. 5C-I), with each series of teeth separated by concavities (e.g. Fig. 5H). In Ecchlorolestes, ovipositor teeth are small, in a linear series approximate to one another (Fig. 6). Chlorolestes tessellatus (Fig. $5 \mathrm{H}$ ) possesses an abbreviated ovipositor similar to Nubiolestes (Fig. 5B). The ovipositor of Nubiolestes is intermediate that of Synlestidae (Fig. 5C-I) and Perilestidae (Fig. 5A), perhaps providing support for Perilestidae being included within Synlestidae.

\section{Results}

Synlestidae s.s. was recovered with $77 \%$ bootstrap support. The earliest branching lineages in the topology were Synlestes and Episynlestes. Ecchlorolestes and Chlorolestes were recovered as a clade (69\%), with the inclusion of Nubiolestes, Megalestes and Phylolestes (Fig. 7). The NCBI sequence of E. nylephtha was of 28 S only (Fig. 8), which may explain why this sequence did not fall within the clade comprising the remaining members of this species. Phylolestes was recovered as sister to Nubiolestes + Chlorolestes (68\%). Within Chlorolestes, C. umbratus was recovered as sister to the remaining Chlorolestes (84\%). C. apricans was recovered as sister to (C. conspicuus (C. elegans (C. fasciatus + C. tessellatus)) $)(73 \%)$. The NCBI sequence for C. tessellatus was $28 \mathrm{~S}$ only (Fig. 8), which may explain why it did not group with the remaining C. fasciatus. 

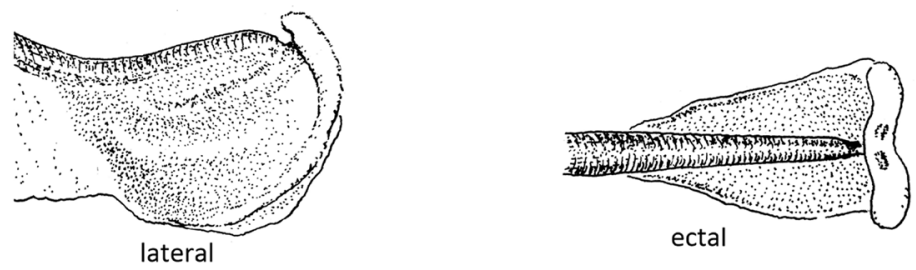

A. Perilestes fragilis: Brazil: Ilha de Marambaia

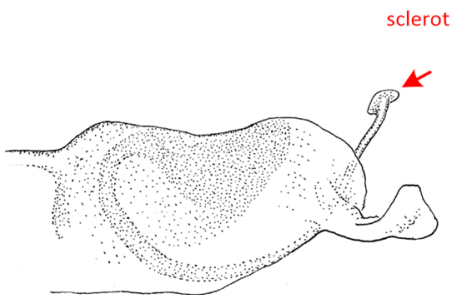

lateral

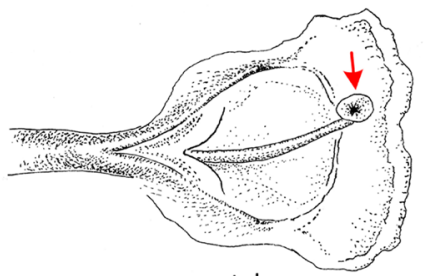

ectal

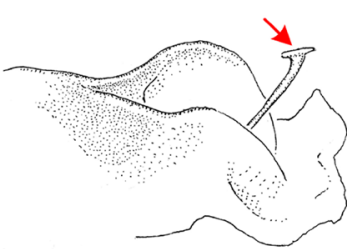

ectolateral

B. Nubiolestes diotoma male: Cameroon, Meme
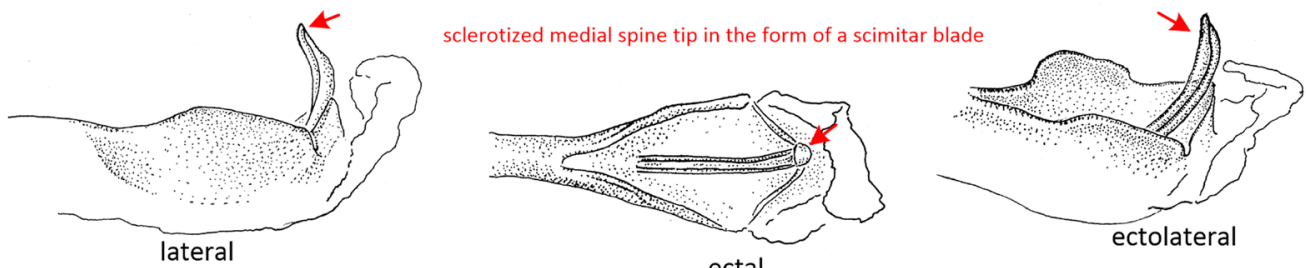

C. Chlorolestes apricans: South Africa, Kubusi River (same for C. conspicuus, C. umbratus)

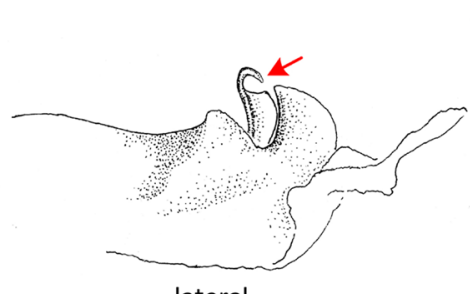

sclerotized medial spine tip in the form of a pitcher plant
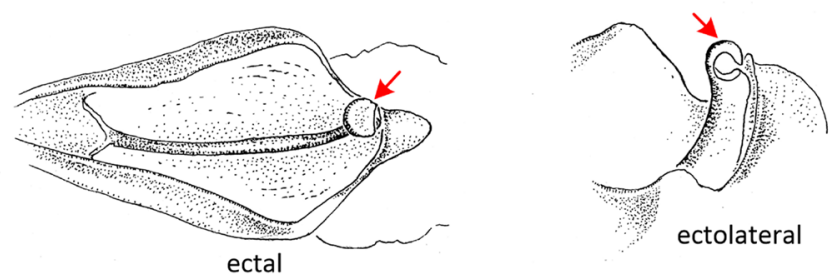

D. Chlorolestes draconicus: South Africa, Mashai River (same for C. elegans, C. fasciatus, C. tessellatus)

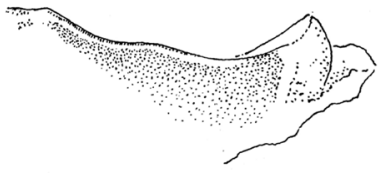

lateral

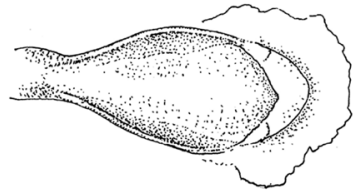

ectal

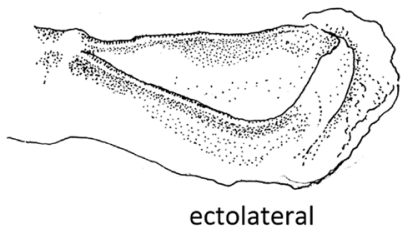

ectolateral

E. Ecchlorolestes nylephtha: South Africa, Elandsbos River (same for E. peringueyi )

Figure 3. Lateral ectal and ectolateral views of apical segment of genital ligula of: (A) Perilestes fragilis, (B) Nubiolestes diotoma, (C) Chlorolestes apricans, (D) Chlorolestes draconicus and (E) Ecchlorolestes peringueyi. Heterospecific armature noted in red.

The median spine located on the ligula of the male secondary genitalia seems to have evolved once, as did a tooth on the caudal appendages. The hood-like structure on the male ligula and evenly spaced concavities between ovipositor teeth were synapomorphies for the grouping of C. elegans, C. fasciatus, C. tessellatus (and C. draconicus, although not sequenced here). The presence of a basal spine on the cercus, an ovipositor with small teeth equidistant from one another, and a medial spine on the ligula, with $\mathrm{RP}_{3}$ originating before the subnodus were synapomorphies for both species of Ecchlorolestes. 

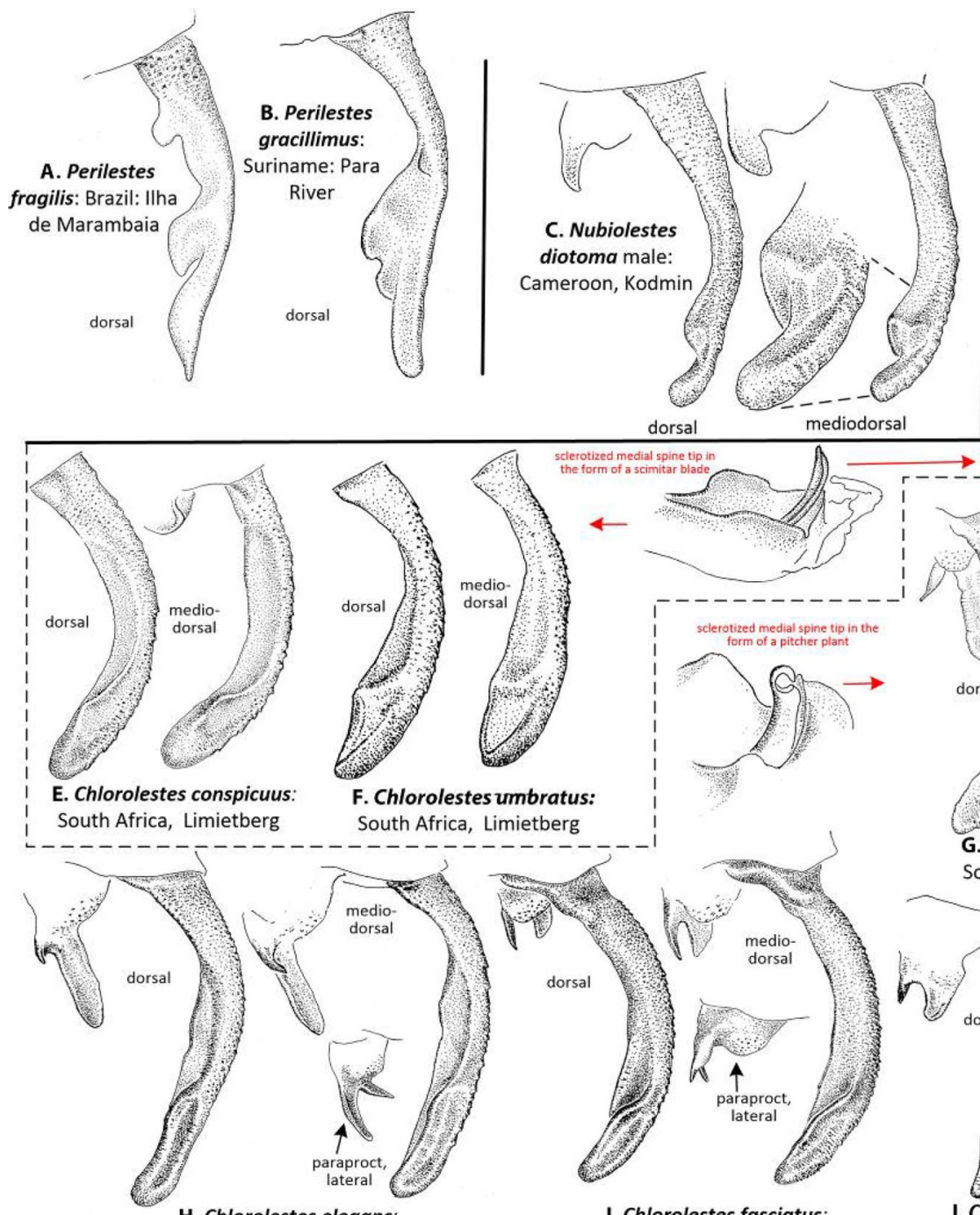

H. Chlorolestes elegans: South Africa, Magoebaskloof

\section{dorsal}

mediodorsal

I. Chlorolestes fasciatus: $\longrightarrow$

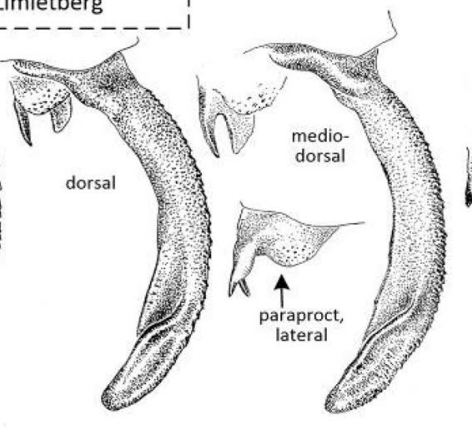

south Africa, Mnweni River

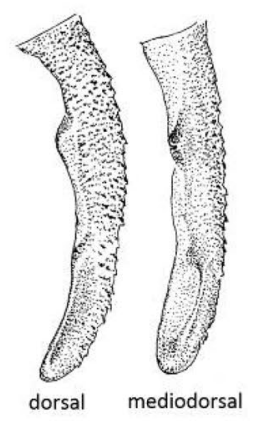

D. Chlorolestes apricans: South Africa, Kubusi River
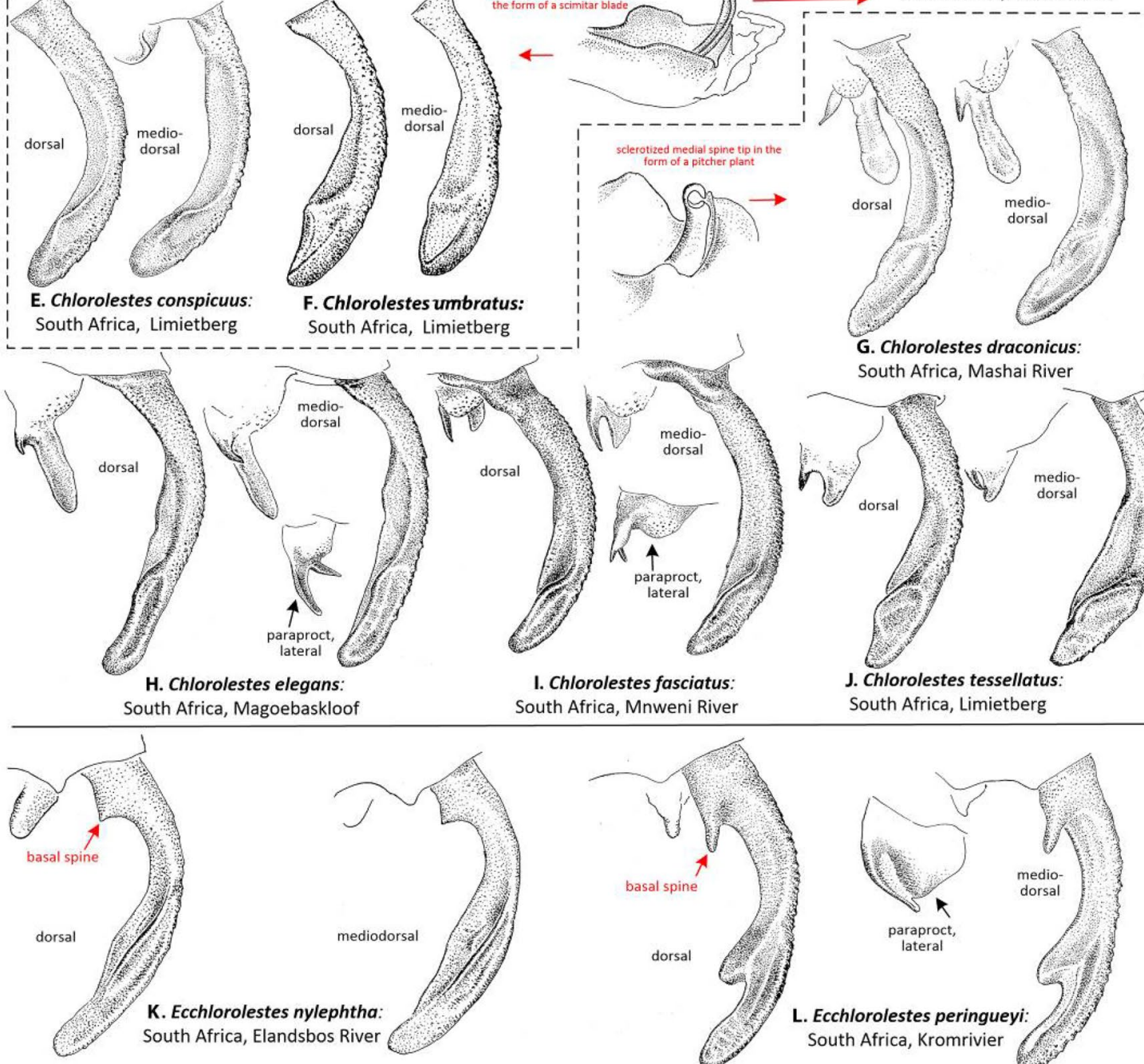

G. Chlorolestes draconicus: South Africa, Mashai River

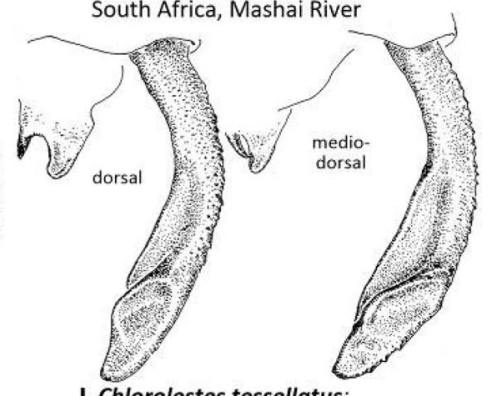

J. Chlorolestes tessellatus: South Africa, Limietberg

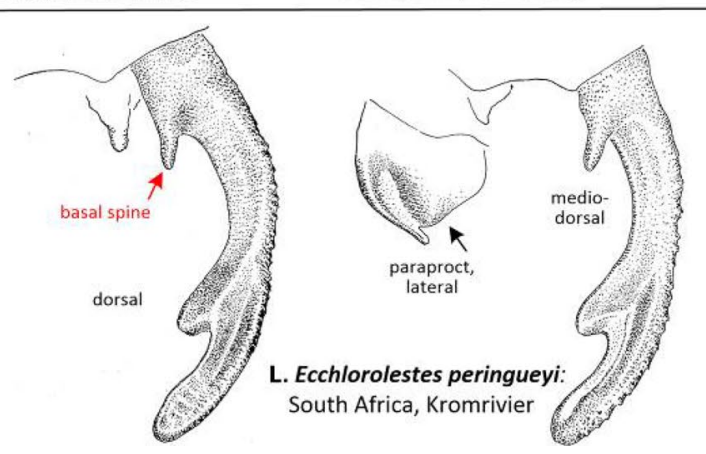

Figure 4. Dorsal and mediodorsal views of right cercus and paraprocts (the latter where shown in lateral view) of: (A) Perilestes fragilis, (B) Perilestes gracillimus, (C) Nubiolestes diotoma, (D) Chlorolestes apricans, (E) C. conspicuus, (F) C. umbratus, (G) C. draconicus, (H) C. elegans, (I) C. fasciatus, (J) C. tessellatus, (K) Ecchlorolestes peringueyi and (L) E. peringueyi. Appendages of Chlorolestes apricans (D), C. conspicuus (E), and C. umbratus (F) have genital armature in the form of a scimitar blade; appendages of C.draconicus $(\mathbf{G})$, C. elegans $(\mathbf{H}), C$. fasciatus (I), and C. tessellatus $(\mathbf{J})$ have genital armature in the form of a pitcher plant.

Biogeographical analyses using the parsimony ancestral state reconstruction function in Mesquite suggest a single African origin of Synlestidae (Fig. 9). Megalestes, recovered as a likely sister to the remaining Synlestidae, occurs in the Oriental Region, and our topology suggests that Phylolestes has an independent bioegeographical origin into the New World, most likely due to dispersal into the Caribbean. 


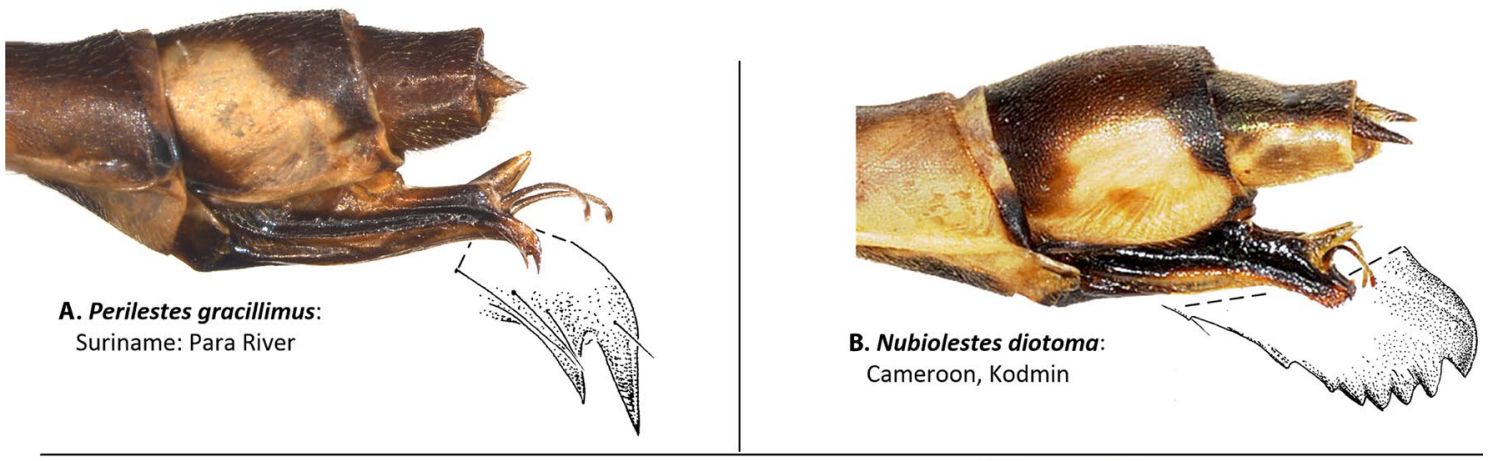

Ovipositor teeth in Chlorolestes
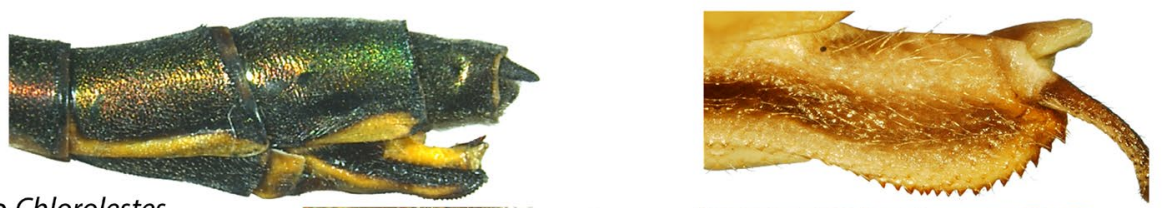

large and robust, limited to

apical portion of ovipositor and separated by concavity in ventral view (e.g. G. Chlorolestes fasciatus)

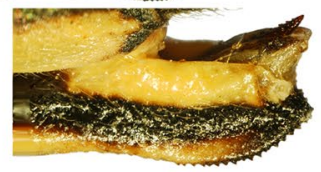

C. Chlorolestes apricans: South Africa, Kubusi River

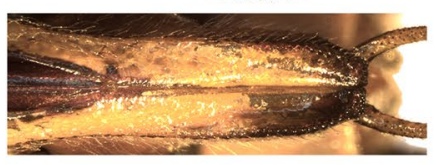

D. Chlorolestes conspicuus: South Africa, Harold Porter Nat Res

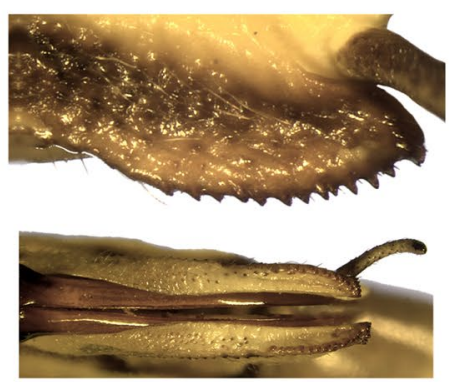

E. Chlorolestes draconicus: South Africa, Sani Pass
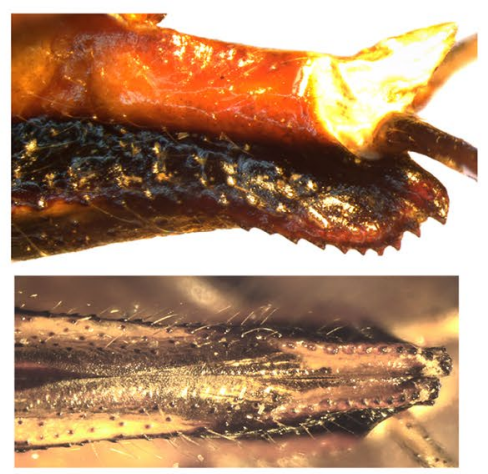

F. Chlorolestes elegans:

South Africa, Duiwelskloof

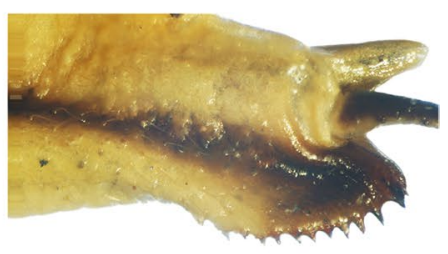

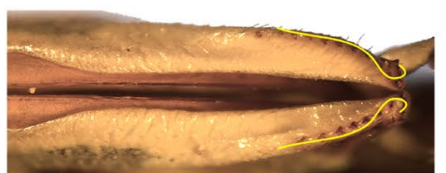

G. Chlorolestes fasciatus: South Africa, Mnweni River

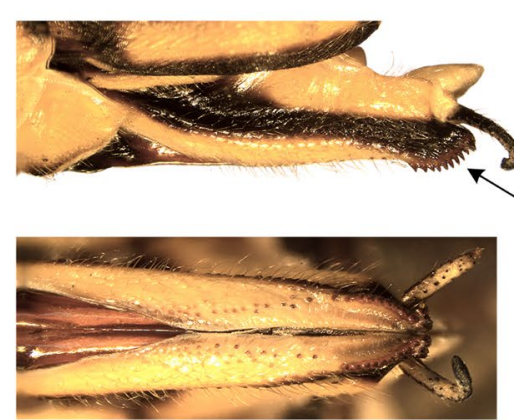

H. Chlorolestes tessellatus South Africa, Limietberg
Ovipositor of Chlorolestes tessellatus perhaps most similar to that of Nubiolestes (see B).

Figure 5. Lateral and ventral views of abdominal segments 9, 10 and ovipositor of: (A) Perilestes gracillimus, (B) Nubiolestes diotoma, (C) Chlorolestes apricans, (D) C. conspicuus, (E) C. draconicus, (F) C. elegans, (G) C. fasciatus, (H) C. tessellatus, and (I) C. umbratus.

\section{Discussion}

Biogeography. The present-day distributions of the Synlestidae-and Odonata in general—reflect millions of years of geographic isolation of South Africa from other areas of the continent, and high-mountain building in the south-west in particular, coupled with a lack of glaciation events for over 200 million years. This has contributed to considerable speciation and endemism ${ }^{6,17}$, particularly in the Cape Floristic Region (CFR), but also in the high KwaZulu-Natal Drakensberg mountains ${ }^{6}$. Although some individuals of Synlestidae species do occur at low 

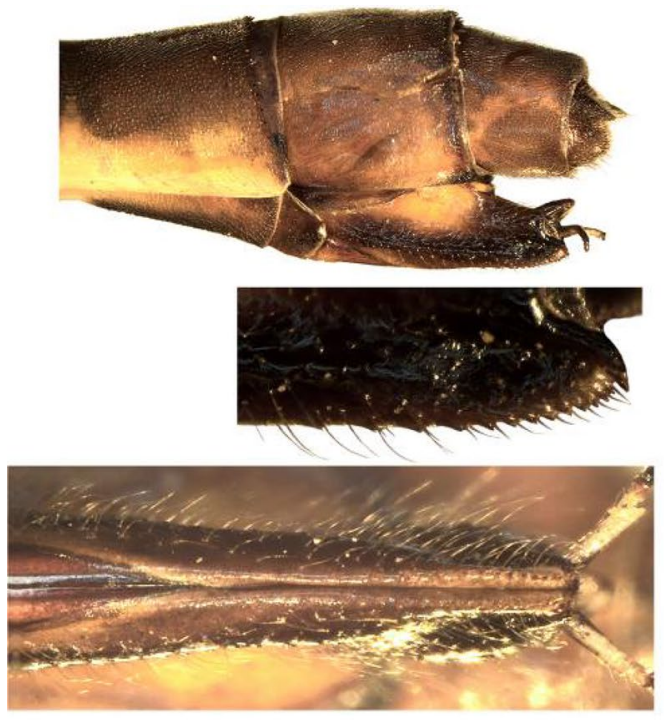

A. Ecchlorolestes nylephtha: South Africa, Elandsbos River
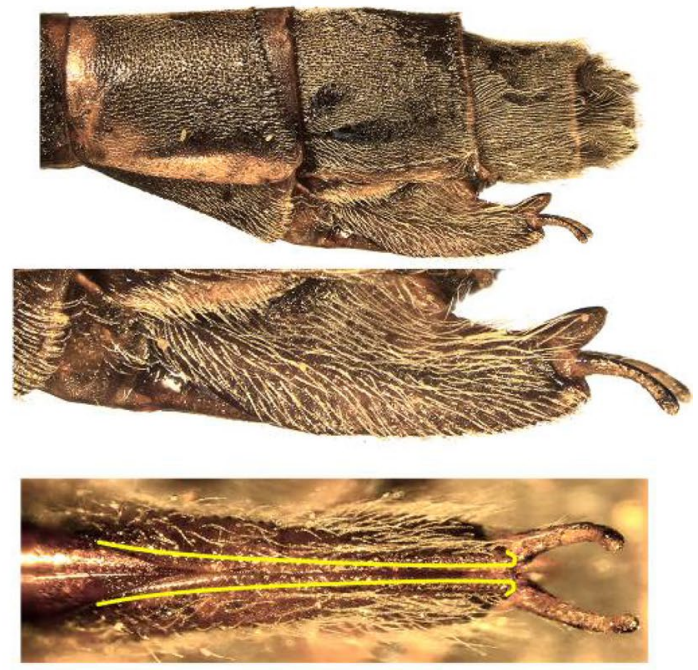

B. Ecchlorolestes peringueyi: South Africa, Eerste Rivier

Figure 6. Lateral view of abdominal segments 9,10 and ovipositor of: (A) Ecchlorolestes nylephtha, and (B) E. peringueyi. Note that the ovipositor teeth in Ecchlorolestes are small and in a linear series approximate to one another in ventral view.

elevations (e.g. C. fasciatus at near sea level at Mtamvuna), most representatives of the family commonly occur at higher elevations ${ }^{18}$, with higher elevations being common for Neotropical Phylolestes. Perilestidae, however, often occur at low elevations in the Amazon basin. In a warming global climate, the preference for high elevations may leave some montane specialists, such as $C$. draconicus without suitable habitat ${ }^{6}$. Isolated populations, such as that of $C$. tessellatus in Sevenweekspoort, at least a hundred kilometers from the nearest population, with arid and unsuitable habitat in between ${ }^{17}$, may face a similar isolationist situation.

Ecchlorolestes was first erected as a genus in 1937 by Barnard $^{12}$. In 1962, Pinhey ${ }^{19}$ suggested that at least $E$. nylephtha should be considered as a member of Chlorolestes, but this was reversed ${ }^{20}$. For example, the two species in the genus are unlike Chlorolestes in their possession of a distinct basal tooth on the superior anal appendages ${ }^{16}$. The tooth is stubby in E. peringueyi (Fig. 4L) and narrower in E. nylephtha (see ${ }^{16}$ for figures of anal appendages, and Fig. $4 \mathrm{~K}$ here). However, other closely related taxa also have a similar tooth to Ecchlorolestes, such as the Australian Synlestes weyersii, whose teeth on the superior appendages greatly resemble E. peringueyi. In the Australian lestid Austrolestes cingulatus (Burmeister), the teeth are similar, although each tooth is much shorter and stubbier than E. peringueyi. Perhaps the presence of a tooth on the superior appendage has simply been lost and gained multiple times, although this requires testing with a thorough morphological evaluation, as animal genitalia evolve rapidly with respect to other morphological traits due to sexual selection ${ }^{21}$. The differences in the ovipositor armature between Chlorolestes (robust teeth, Fig. 5C-I) and Ecchlorolestes (teeth small, Fig. 6) may be an adaptation to laying in soft tissue (lichens for E. peringueyi, and ferns/mosses for E. nylephtha), in comparison with harder tissue for the southern African Chlorolestes (terminal twiglets of sclerophyllous vegetation). A phylogenetic hypothesis based on fossil and extant zygopteran taxa would provide further insight into the evolution of synlestid morphology.

In general, Chlorolestinae have very petiolate wings, and occur in association with montane streams, especially deposition pools. Their geological history is not well known, but there are fossils of putative Synlestidae, such as Eolestes ${ }^{22-24}$ from the Eocene (roughly 56-34 million years ago) and Gaurimacia sophiae ${ }^{25}$ from the Late Jurassic, Early Cretaceous (roughly 145 mya).

Extant Synlestidae in the new world. There is but one New World representative of Synlestidae, Phylolestes in the Caribbean: is this taxon there due to dispersal? The fossil Eolestes described by Cockerell ${ }^{22}$ and considered by Nel and Paicheler ${ }^{23}$ to be a putative Synlestidae, was recovered from the New World, in the United States of America. Perhaps Synlestidae species were once more widespread, but have since gone extinct, except for representatives in the Caribbean, Australasia, and southern Africa. If Perilestidae are indeed Synlestidae, as our topology and morphological data suggest, then the Neotropical distribution of Phylolestes may instead reflect an ancestral range that spanned Gondwana. The geological age of Hispaniola is Late Cretaceous to early Cenozoic $^{26}$. Perhaps Phylolestes colonized or speciated on this island, while other Neotropical members of the family went extinct. An autapomorphy for Synlestidae + Perilestidae is the strongly arched CuP (Fig. 2) at its base where it meets the extremity of the quadrangle. With this revised status, New World Synlestidae are then comparatively the most species rich with 21 species compared with taxa from Asia (19), Africa (9) and Australia (7).

Do larval characteristics support or refute uniting Perilestidae and Synlestidae? We considered all larval descriptions of perilestids $s^{27-30}$ and synlestids known to us ${ }^{31-36}$. The caudal lamellae in all genera are very similar in all genera, but the larva of Megalestes (Synlestidae) differs more from all of the other genera (Perilestes, Perissolestes, Phylolestes, Chorismagrion, Episynlestes, Synlestes and Nubiolestes) referenced above. The shape of the 


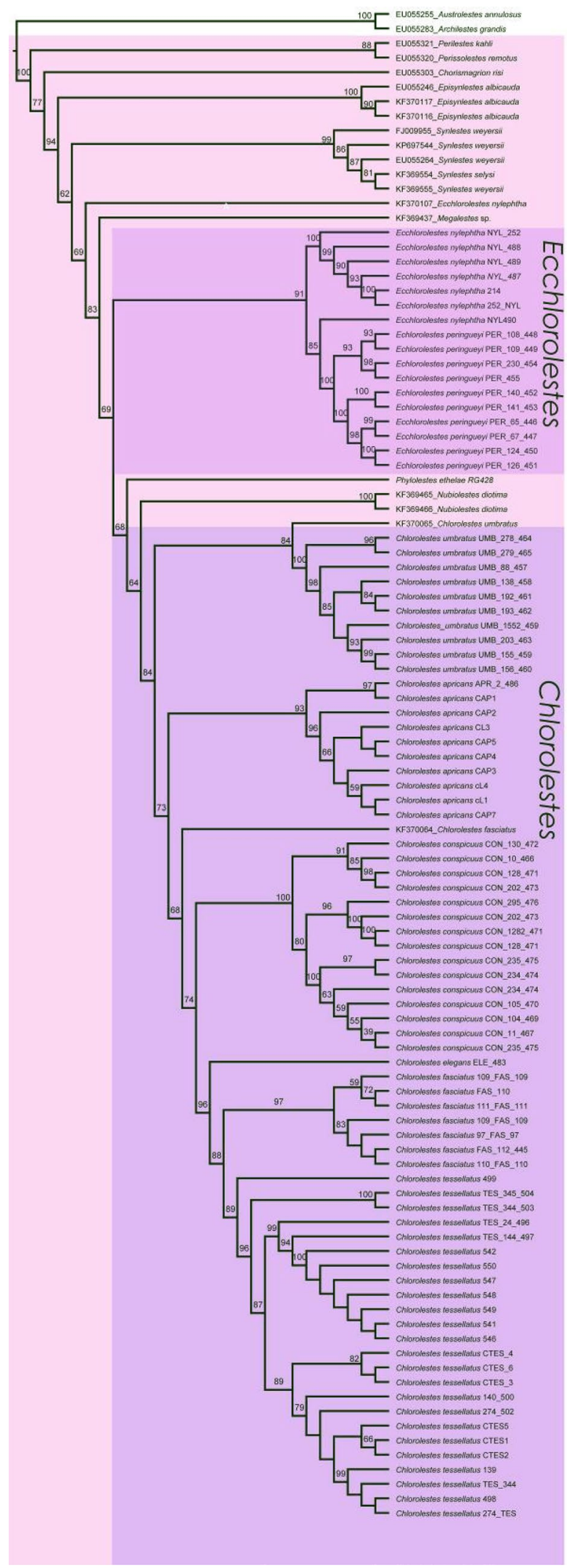

Figure 7. IQtree consensus tree, with morphological groups labelled (A-D) and bootstrap values reported above branches. 


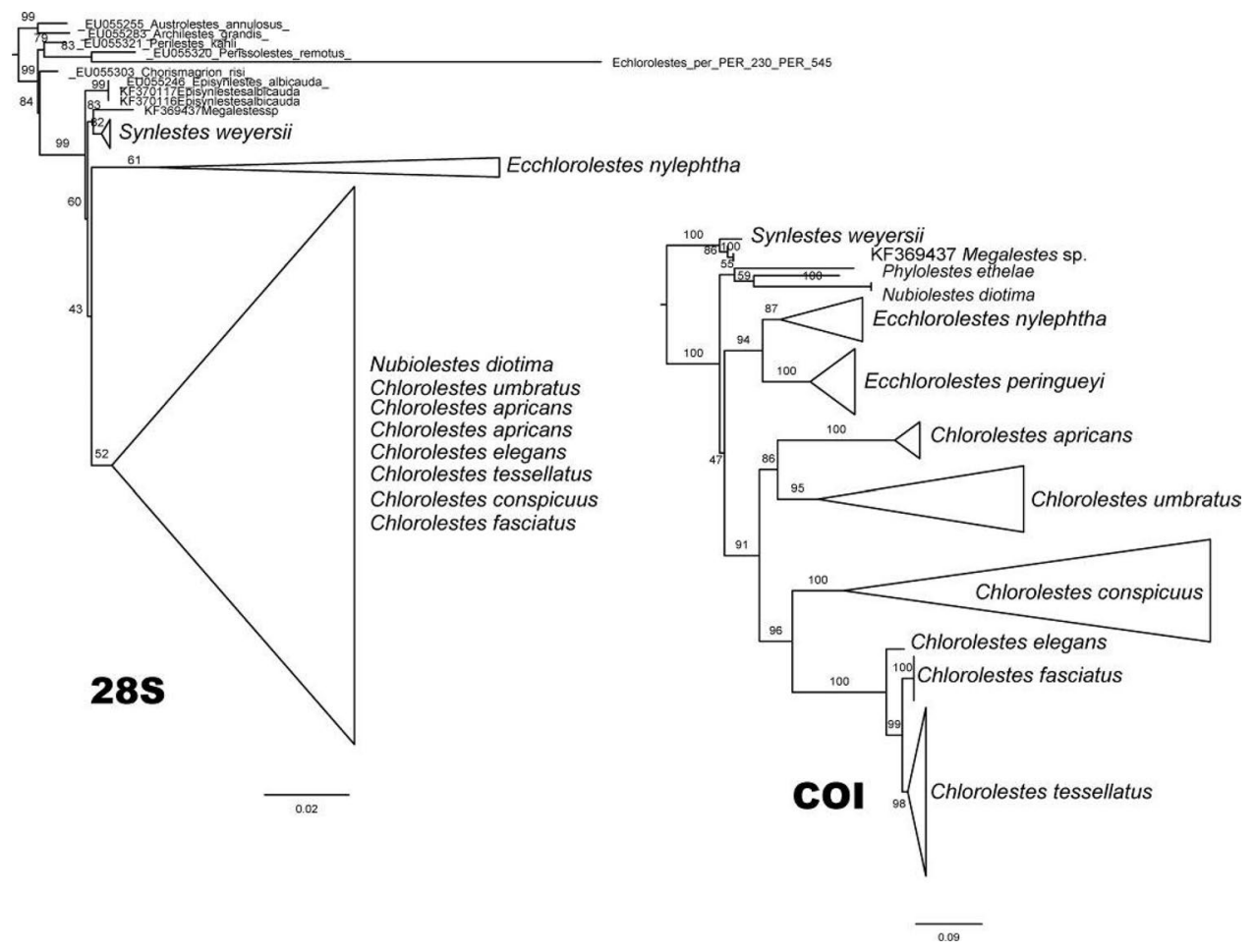

Figure 8. Gene trees of COI and $28 \mathrm{~S}$ sequences based on IQtree consensus tree, with bootstrap values reported above branches.

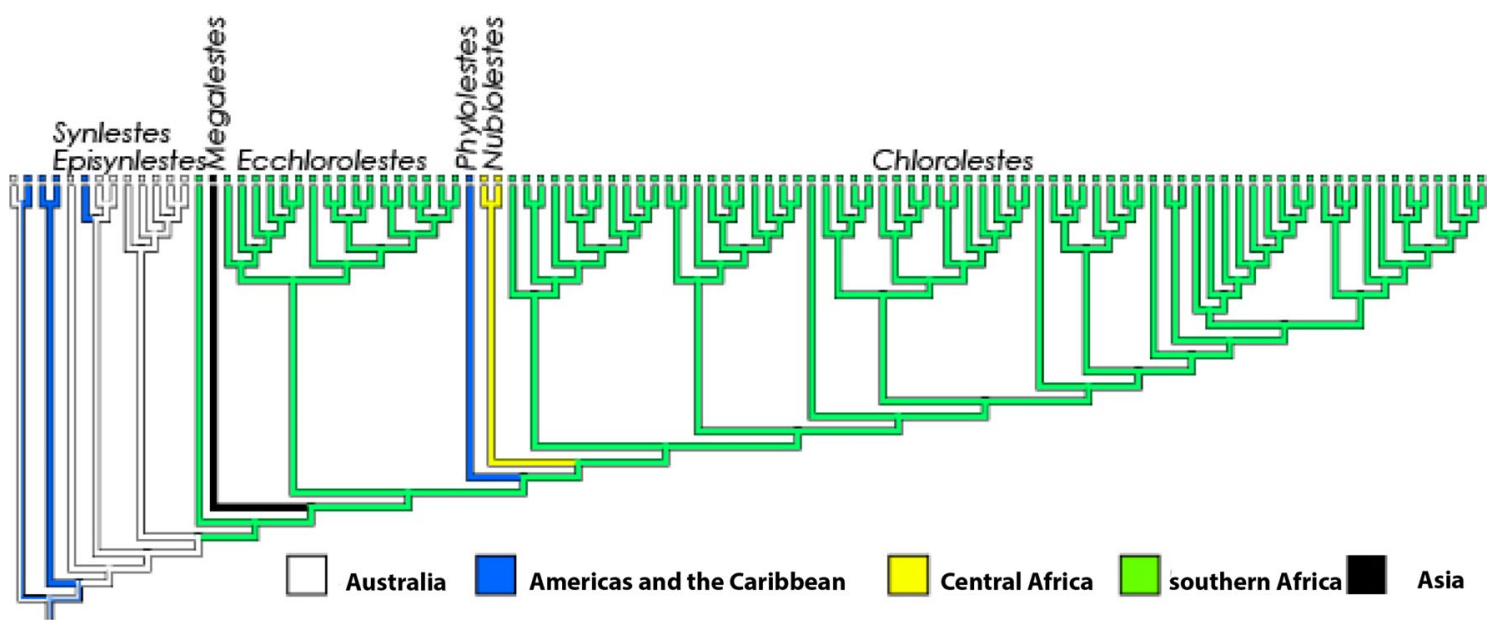

Figure 9. Mesquite ancestral state mapping tree suggesting biogeographical ranges for present and ancestral groups.

labium and delicate spider-like legs in Megalestes differ from all of the other genera listed above. In summary, the differences among genera within Synlestidae, based on the published literature, seem to be at least as great, or greater, than differences between Perilestidae and Synlestidae. Any argument to sustain Perilestidae as separate from Synlestidae based on larvae does not seem to be particularly significant. Arguments as to differing altitude preferences also do not seem to be valid reasons for maintaining Perilestidae as separate from Synlestidae, as these can vary even with a single genus. For example, C. draconicus only occurs at high elevations, but many others either occur in a wide elevational range, (C. fasciatus) or even at low elevations (C. tessellatus, C. conspicuus). It is therefore unlikely that elevation provides a valid reason for maintaining the two families as separate.

Taxonomy and the status of the southern African genera in Synlestidae. Based on our results, Ecchlorolestes and Chlorolestes are valid taxonomic groups, as also suggested by larval morphology ${ }^{34}$. Some subgroups within Chlorolestes have been suggested based on wing banding. Chlorolestes umbratus, C. tessellatus, C. 
fasciatus, C. elegans possess banded wings in all or some populations. Our topology suggests that this banding is perhaps not so much a reflection of evolutionary history as localized selection pressure. For example, wing banding in C. tessellatus populations varies according to geographical area, with some populations in the Eastern Cape with heavily banded wings, and others, for example in KwaZulu-Natal with no banding at all. One population, also in KwaZulu-Natal, has very weakly banded wings ${ }^{37}$. Similar polymorphism in wing maculation occurs in Sinolestes editus Needham and some species of Orolestes McLachlan, 1895, which belong to the family Lestidae $)^{38,39}$. Here, we propose sinking the family Perilestidae within the Synlestidae based on (a) their position as sister to the large clade containing Nubiolestes and the Synlestidae, (b) morphological characters, such as the strongly arched $\mathrm{CuP}$ at its base where it meets the extremity of the quadrangle and ovipositor, described above.

\section{Conclusions}

Ecchlorolestes and Chlorolestes are monophyletic. We suggest that given the molecular topology and morphological data, Perilestidae should be considered members of the Synlestidae. Phylolestes is sister to Chlorolestes, suggesting that there was an African origin of the clade containing Nubiolestes, Ecchlorolestes, Phylolestes and Chlorolestes, and subsequent dispersal to the Caribbean by Phylolestes, unless Perilestidae are also included within the family, in which case perhaps a broader origin is possible, as supported by the fossil evidence and Mesquite analysis.

Received: 24 April 2020; Accepted: 19 August 2020

Published online: 15 September 2020

\section{References}

1. Tillyard, R. J. The biology of dragonflies. (Cambridge University Press, 1917).

2. Tillyard, R. J. Insects of Australia and New Zealand. (Angus and Robertson, 1926).

3. Samways, M. J. \& Simaika, J. P. Manual of freshwater assessment for South Africa: dragonfly Biotic Index. Suricata 2, 1-224 (2016).

4. Garrison, R. W., von Ellenrieder, N. \& Louton, J. A. Damselfly genera of the New World: An Illustrated and Annotated Key to the Zygoptera. (The Johns Hopkins University Press, 2010).

5. Payra, A., Deepak, C. K., Tripathy, B., Mondal, K. \& Chandra, R. R. K. New distributional record of Megalestes irma Fraser, 1926 (Odonata: Zygoptera: Synlestidae), a damselfly from Arunachal Pradesh, Eastern Himalayas India. Euroas. Entomol. J. 16, 314-318 (2017).

6. Torres-Cambas, Y. et al. An update on the distribution of threatened odonate species from the Greater Antilles. Int. J. Odonatol. https://doi.org/10.1080/13887890.2014.928241 (2015).

7. Parker, S. R. Sequence navigator. in Sequence Data Analysis Guidebook 145-154 (Springer, 1997).

8. Thompson, J. D., Gibson, T. J., Plewniak, F., Jeanmougin, F. \& Higgins, D. G. The CLUSTAL X windows interface: flexible strategies for multiple sequence alignment aided by quality analysis tools. Nucleic Acids Res. https://doi.org/10.1093/nar/25.24.4876 (1997).

9. Kalyaanamoorthy, S., Minh, B. Q., Wong, T. K. F., Von Haeseler, A. \& Jermiin, L. S. ModelFinder: fast model selection for accurate phylogenetic estimates. Nat. Methods 14, 587-589 (2017).

10. Massidon, W. P. \& Maddison, D. R. Mesquite: A modular system for evolutionary analysis. Version 3.4. https://www.mesquitepr oject.org (2018) https://doi.org/10.1017/CBO9781107415324.004.

11. Kennedy, C. H. Forty-two hitherto unrecognized genera and subgenera of Zygoptera. Ohio J. Sci. 21, 83-88 (1920).

12. Barnard, K. H. Notes on dragon-flies (Odonata) of the SW Cape, with descriptions of the nymphs, and of new species. S. Afr. Museum 32, 169-260 (1937).

13. Pinhey, E. C. G. The dragonflies of southern Africa. Transvaal Museum Mem. 5, xv + 335 (1951).

14. Tarboton, W. \& Tarboton, M. A field guide to the damselflies of South Africa. (Warwick \& Michèle Tarboton, 2005).

15. Tarboton, W. \& Tarboton, M. A guide to the dragonflies and damselflies of South Africa. (Struik Nature, 2015).

16. Samways, M. J. Dragonflies and damselflies of South Africa. Pensoft Ser. Faun. 70, 1-297 (2008).

17. Samways, M. J. National red list of South African Odonata. Odonatologica 35, 341-368 (2006).

18. Samways, M. J. Taxon turnover in Odonata across a $3000 \mathrm{~m}$ altitudinal gradient in southern Africa. Odonatologica 18, 263-274 (1989).

19. Pinhey, E. A descriptive catalogue of the Odonata of the African continent (Companhia de Diamantes de Angola, Serviços Culturais, 1962).

20. Davies, D. A. L. \& Tobin, P. The Dragonflies of the World: a systematic list of the extant species of Odonata. Soc. Int. Odonatol. 1, (1984).

21. Eberhard, W. G. Sexual selection and animal genitalia. (Harvard University Press, 1985).

22. Cockerell, T. D. A. A dragon-fly from the Eocene of Colorado (Odonata: Agrionidae). Entomol. News 51, 103-105 (1940).

23. Nel, A. \& Paicheler, J.-C. Les Lestoidea (Odonata, Zygoptera) fossils: un inventaire critique. Ann. Paléontologie 80, 1-59 (1994).

24. Greenwalt, D. E. \& Bechly, G. A re-description of the fossil damselfly Eolestes syntheticus Cockerell, 1940 (Odonata: Zygoptera: Eolestidae n. fam.) with description of new taxa from the Eocene of North America. Zootaxa 3887, 138-156 (2014).

25. Vasilenko, D. V. New damselflies (Odonata: Synlestidae, Hemiphlebiidae) from the Mesozoic Transbaikalian locality of Chernovskie Kopi. Paleontol. J. 39, 280-283 (2005).

26. Mann, P., Draper, G. \& Lewis, J. F. An overview of the geologic and tectonic development of Hispaniola. Geologic and tectonic development of the North America-Caribbean plate boundary in Hispaniola. (Geological Society of America Special Paper, 1991).

27. Santos, N. D. dos. Contribução ao conhecimento da fauna do Estado da Guanabara. 70-Descrição da ninfa de Perilestes fragilis Hagen in Selys, 1862 e notas sobre o imago (Odonata: Perilestidae). Atas da Soc. Biol. do Rio Janeiro 12, 303-304 (1992).

28. Neiss, U. G. \& Hamada, N. The larva of Perilestes attenuatus Selys, 1886 (Odonata: Perilestidae) from Amazonas Brazil. Zootaxa 58, 53-58 (2010).

29. Román-Heracleo, J., Springer, M. \& Ramírez, A. The larva of Perissolestes remotus (Williamson \& Williamson, 1924) (Zygoptera: Perilestidae). Int. J. Odonatol. 21, 173-179 (2018).

30. Westfall, M. J. Taxonomic relationships of Diceratobasis macrogaster Christiansen and Phylolestes ethelae of the West Indies as revealed by their larvae (Zygoptera: Coenagrionidae, Synlestidae). Odonatologica 5, 65-76 (1976).

31. Fraser, F. C. The nymphs of Synlestes tropicus Tillyard, Chorismagrion risi Morton, Oristicta filicola Tillyard and Lestoidea conjuncta Tillyard: With description of the female of the latter and further notes on the male. Aust. Zool. 12, 284-292 (1927).

32. Theischinger, G., Watson, J. A. L. \& Rowe, R. J. Larvae of Australian synlestidae (Odonata: Zygoptera. J. Aust. Entolmol. Soc. 32, 113-119 (1993). 
33. Wilmot, B. C. Descriptions of final-instar larvae of Chlorolestes Sélys ( Odonata : Zygoptera; Synlestidae ) from southern Africa, with a key to species. Ann. East. Cape Museums 6, 21-43 (2007).

34. Deacon, C., Simaika, J. P. \& Samways, M. J. Description of final instar larvae of Ecchlorolestes Selys spp. from South Africa (Odonata: Synlestidae). Odonatologica 46, 319-330 (2017).

35. Xu, Q. H. Redescription of the final stadium larva of Megalestes heros Needham from Fujian, China, with discussion of the characters of genus Megalestes Selys (Odonata: Zygoptera: Synlestidae). Zootaxa 4728, 381-384 (2020).

36. Vick, G. S. Notes on some damselfly larvae from Cameroon (Zygoptera: Perilestidae, Amphpterygidae, Platycnemididae). Odonatologica 27, 87-98 (1998).

37. Samways, M. J. Open and banded wings: Hypotheses on damselfly wing position (Zygoptera). Odonatologica 35, 67-73 (2006).

38. Wilson, K. D. P. \& Reels, G. T. Odonata of Guangxi Zhuang Autonomous Region, China, part I: Zygoptera. Odonatologica 8, 107-168 (2003).

39. Zhang, H.-M. The dragonflies and damselflies of China. (Chongqing University Press, 2019).

\section{Acknowledgements}

While working on this project, J.L. Ware was funded in part by NSF Postdoctoral Fellowship 0804424 and later by NSF DBI NSF \#1564.

\section{Author contributions}

J.S. and J.W. designed the research. J.W. did the phylogenetic analyses, R.G. analyzed morphological features. All authors wrote the main manuscript text. R.G., J.W. J.S. prepared figures and tables. All authors reviewed the manuscript.

\section{Competing interests}

The authors declare no competing interests.

\section{Additional information}

Supplementary information is available for this paper at https://doi.org/10.1038/s41598-020-72001-x.

Correspondence and requests for materials should be addressed to J.P.S.

Reprints and permissions information is available at www.nature.com/reprints.

Publisher's note Springer Nature remains neutral with regard to jurisdictional claims in published maps and institutional affiliations.

Open Access This article is licensed under a Creative Commons Attribution 4.0 International License, which permits use, sharing, adaptation, distribution and reproduction in any medium or format, as long as you give appropriate credit to the original author(s) and the source, provide a link to the Creative Commons licence, and indicate if changes were made. The images or other third party material in this article are included in the article's Creative Commons licence, unless indicated otherwise in a credit line to the material. If material is not included in the article's Creative Commons licence and your intended use is not permitted by statutory regulation or exceeds the permitted use, you will need to obtain permission directly from the copyright holder. To view a copy of this licence, visit http://creativecommons.org/licenses/by/4.0/.

(C) The Author(s) 2020 